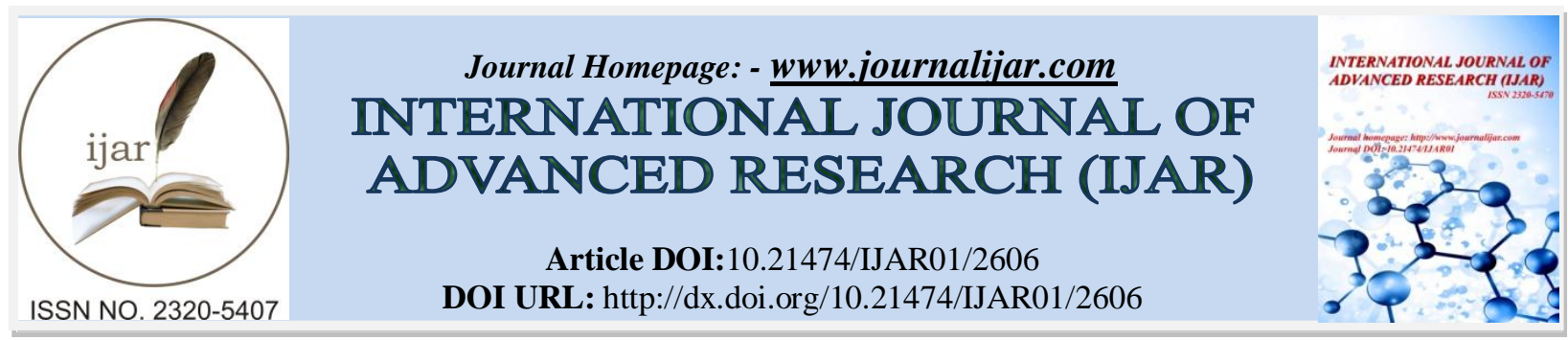

RESEARCH ARTICLE

\title{
A COMPARATIVE STUDY OF ENVIRONMENTAL AWARENESS AMONG SECONDARY SCHOOL TEACHERS IN CHAMBA DISTRICT OF HIMACHAL PRADESH, INDIA.
}

Baljeet Singh Patial.

BTC DAV College Banikhet, Dalhousie, Chamba, India.

\section{Manuscript Info}

\section{Manuscript History}

Received: 28 October 2016

Final Accepted: 27 November 2016

Published: December 2016

Key words:-

Environmental awareness, secondary school teachers and gender.

\section{Abstract}

The present study identifies the environmental awareness of secondary school teachers in relation to gender, type of board and courses of studies. One thousand teachers were selected from secondary schools inChambaDistrict of Himachal Pradesh (India) affiliated to CBSE and H.P. Board. A questionnaire was used as research instrument. For measuring environmental awareness self-made questionnaire was used, Mean, SD and ' $t$ '-value were usedto analyzed data. The study will influence in type of board, gender and course of studies on the level of teachers of environmental understanding.

Copy Right, IJAR, 2016,. All rights reserved.

\section{Introduction:-}

Environmental education is the process of recognizing values and classifying concepts in order to develop skills and added tools necessary to understand and appreciate the interrelationship amongst man, his culture and his biophysical surrounding ${ }^{1-2}$. It is through the environmental education that people will be aware of the need for improving the environment. Environmental education is also refers to organized efforts to teach how natural environments function and, particularly, how human being can manage their behavior and ecosystems in order to live sustainably.

The past fifty years have been growing international recognition that the challenges associated with environmental degradation and sustainable development have important implications for, and connected with, education and schooling. The concept of environmental education is now wide spreading national educational policies, curriculum documents, curriculum development initiative and conservation strategies ${ }^{1-5}$.

Environmental awareness on the other hand is "to understand the fragility of our environment and the importance of its protection"

Environmental awareness is classified into two aspects: perception of environmental problems and behavioral inclination to protect the environment. The perception is the people should have knowledge of environment and their issues. The behavior inclination is to protect the environment includes two major aspects: firstly, the value of environmental protection in people minds which indicated by the balance between environmental protection and economic development and also the willing to pay for the protection of the environment; secondly, attitudes about participating in the environmental protection ${ }^{8}$.It emphasizes the basic aim of environmental education as, "To develop a world population that is aware of and concerned about the environment, its associated problems, so that the population will have the knowledge, skill, attitudes, motivation and commitment to work individually and collectively towards the solutions of current problems and prevention of new ones". 
In order to protect and conserve the environment, enabling people to lead quality life, emphasis has been laid on environmental education in both formal and non-formal education system.In formal system of education, teachers can play an important role in educating their students about environmental related issues ${ }^{9}$.

Environment awareness and understanding among the people are, at once, consequences of environmental education and influences on the environmental process. Curriculum in educational institutions would necessary change with the support of well-informed people. Common information and shared understandings are therefore important not only for mobilizing public support, but carrying out consultative work and participatory approaches in all fields ${ }^{1-8}$. By and large, research in this area indicates that although environmental education is taken up as a subject in the curriculum the subject faces certain limitation with regard to its proper implication. The teacher should be aware of the environmental education aspects only then he can make the future generation aware of the environmental problems and their solutions.

World educators and environmental specialists have repeatedly pointed out that a solution to environmental awareness and its proper understanding which should be deeply rooted in the education system at all levels of school education $^{6,10}$.

In this present context the need for environmental awareness of teachers is must. It is very much essential need for each individual to develop an awareness of protection and preservation towards environment. Air, water and soil pollution is on the increase. Degradation of environment results in many problems. Therefore, there is a great need to protect and preserve the environment. The role of teachers would go a long way in achieving such desire goals. In order to create awareness towards environment it is necessary to know what intensities of awareness they possess in these areas. So, in this paper a comparative study of environmental awareness in teachers of Chamba region in Himachal Pradesh has been done.

\section{Objectives of the study:-}

The objectives of study are:

1. To see difference in science, art and commerce teachers of secondary level with respects to their level of environmental awareness.

2. To compare the teachers of CBSE and HP Board with respect to their level of environmental awareness.

3. To compare the male and female teachers of secondary level with regards to their level of environmental awareness.

Hypotheses of the Research:-

The hypotheses formulated for the present study are as follows:

1. There exists no significant difference in environmental awareness between secondary school teachers of science, arts and commerce.

2. There exists no significant difference in environmental awareness between secondary school teachers of CBSE and HP Board.

3. There exists no significant difference in environmental awareness between the male and female secondary school teachers.

\section{Research Methodology:-}

The first task of investigation is to select appropriate methodology of research. There are several methods of research. Research is determined by the nature of the problem. The present study attempts to study the awareness towards environment among the teachers of secondary schools with dissimilar subjects. The study was conducted in Chamba region of Himachal Pradesh.

\section{Sampling size:-}

Sample is both necessary and advantageous because by sampling we study the problem at reduced cost, at greater speed, with greater scope and with greater accuracy.

To serve a useful purpose, sampling should be adequate and unbiased or representative. In the present study the investigator selected samples from different secondary schools of Chamba District of Himachal Pradesh. After selecting schools, 1000 teachers (450 male and 550 female) were selected randomly from these selected schools teaching with dissimilar subjects. The teachers were selected from both government and private schools. The 
average teaching experience ranging was from 6 to 15 years. The breakup of the sample is being presented in the Table-1.

Table1:- Breakup of the sample

\begin{tabular}{|c|c|c|c|c|c|}
\hline \multirow{2}{*}{ SUBJECT } & \multicolumn{2}{|c|}{ MALE TEACHER } & \multicolumn{2}{c|}{ FEMALE TEACHER } & TOTAL \\
& $\begin{array}{c}\text { CBSE } \\
\text { Board }\end{array}$ & H.P. Board & CBSE Board & H.P. Board & \\
\hline Arts & 80 & 120 & 100 & 130 & 430 \\
\hline Commerce & 40 & 50 & 55 & 65 & 210 \\
\hline Science & 80 & 80 & 90 & 110 & 360 \\
\hline H.P. Board Teacher & & 250 & & 305 & 555 \\
\hline CBSE Board Teacher & 200 & & 245 & & 445 \\
\hline
\end{tabular}

\section{Tool:-}

The tool used in the present investigation was self-made questionnaire whose reliability and validity was tested. The reliability coefficient of the questionnaire by test-retest method was found to be +0.99 . After standardizing the tool, final draft of questionnaire consisted of 50 items, including 15 from general awareness from day to day life, 15 from air pollution, 15 from water and noise pollution and 5 were related from global warming. The contrivance was used for present study was questionnaire.The questionnaire was distributed, administered and collected by researcher. To shun any terminology difficulties in the test and conceptual misunderstanding, a half day discussion was made with the respondent and researcher so that respondents can response clearly and correctly.

\section{Data Analyses:-}

The investigator used normative survey method to collect data for the present study. A questionnaire is used as a tool for gathering the required data. The questionnaire is prepared by the investigator himself. The items were of multiple choices.

In order to analyze and interpret the questionnaire scores the investigator adopts the following statistical techniques. Mean, Standard deviation, Standard error and t-test are the statistical techniques used in the analyses of data.

\section{Result and Discussion:}

The data was analyzed to find answers to the hypothesis set for the study. The first objective of the study was to compare secondary level teachers regarding their courses of study. Hypothesis of this objective was that there is no significant difference between the teachers of three (Arts, Commerce and Science). The environmental awareness score of secondary school teacher belonging to Arts. Commerce and Science stream have been given in Table-2.

Table2:- Comparison of mean and S.D. of Arts, Science and Commerce Teachers.

\begin{tabular}{|c|c|c|c|}
\hline Course of Studies & No. of Teachers & Mean & SD \\
\hline Arts & 430 & 44.35 & 7.26 \\
\hline Commerce & 210 & 42.60 & 8.26 \\
\hline Science & 360 & 46.15 & 6.80 \\
\hline
\end{tabular}

From the above table it is evident that science teachers scored highest mean score and the lowest mean score was that of the commerce teachers. This indicates that subjects plays an important role regarding creating environmental awareness. To measure the mean score of these difference, 't' value also calculated which is given in Table-3.

Table3:- Comparison environmental awareness score of secondary school teachers in relation to their courses of

\begin{tabular}{|c|c|c|c|c|c|}
\hline Groups Compare & Number $(\mathbf{N})$ & Mean & S.D. & t-test & $\mathbf{P}$ \\
\hline \multirow[t]{2}{*}{ Arts vs. Commerce } & 430 & 44.35 & 7.26 & \multirow[t]{2}{*}{3.06} & \multirow[t]{2}{*}{0.05} \\
\hline & 210 & 42.60 & 8.26 & & \\
\hline \multirow[t]{2}{*}{ Arts vs. Science } & 430 & 44.35 & 7.26 & \multirow[t]{2}{*}{3.86} & \multirow[t]{2}{*}{0.05} \\
\hline & 360 & 46.15 & 6.80 & & \\
\hline \multirow[t]{2}{*}{ Science vs. Commerce } & 360 & 46.15 & 7.12 & \multirow[t]{2}{*}{4.98} & \multirow[t]{2}{*}{0.05} \\
\hline & 210 & 41.35 & 8.46 & & \\
\hline
\end{tabular}


From the above Table-3 it is observed that ' $t$ ' value between the means of arts and commerce teachers was found to be 3.06 which were significant at 0.05 level, this reveals the fact that science and arts teacher differ significantly on environmental awareness. Similarly ' $t$ '- value between arts and science teachers on environmental awareness scale was found to be 3.86 , it indicates that arts and science teachers significantly different 0.05 level. Science and commerce teachers were also significantly differ at 0.05 level.

Second objective of this study was to compare the teachers belonging to different boards (CBSE Board and HP Board). The teachers of CBSE Board achieved greater score than HP Board.

Table4:- Statistical difference indicating types of institution on the environmental awareness

\begin{tabular}{|c|c|c|c|c|c|}
\hline Boards & Number (N) & Mean & S.D. & t-test & P \\
\hline CBSE & 445 & 44.10 & 8.58 & \multirow{2}{*}{0.94} & Not significant \\
\hline HP Board & 555 & 45.16 & 7.02 & & \\
\hline
\end{tabular}

From the Table-4 it is apparent that teachers of CBSE Board obtained higher score on environmental awareness but when the two groups of these teachers were compared it was found that no significant difference exist on environmental awareness because ' $t$ ' is not found significant at any level. Thus the null hypothesis is accepted regarding this objective.

The third objective of this study was to compare the male and female secondary school teachers regarding their environmental awareness score. When male and female teachers compared regarding their environmental awareness, female teachers were found to be more intent, vigilant, more sensitive and aware than male teachers. The summary of result has been presented in Table-5.

Table5:- Comparison of the Male and Female Secondary school teachers with regards to their environmental awareness score.

\begin{tabular}{|c|c|c|c|c|c|}
\hline Boards & Number $(\mathbf{N})$ & Mean & S.D. & t-test & P \\
\hline Male & 450 & 41.62 & 8.98 & 4.76 & 0.05 \\
\hline Female & 550 & 44.08 & 8.25 & & \\
\hline
\end{tabular}

From the Table-5 it is clear that mean of female teacher on environmental awareness scale. The ' $t$ ' value between the means of male and female teachers on environmental awareness was found to be 4.76 which was significant at 0.05 level.

\section{Conclusion:-}

The teacher plays a vital role in laying the foundation of society. The present study revealed the following significant conclusions with respect to the environmental awareness of school teachers in relation to dissimilar subjects and different board:

- Science and arts teachers had more environment awareness in comparison tocommerce teachers.

- CBSE teachers had more environmental awareness in comparison to HP Board teachers because of the rich educational climate and method of teaching of CBSE schools with compare to HP Board schools.

- The female teachers had more environmental awareness in comparison to male teachers because of female teachers are normally so much emotionally involved with the environment and they also attached with society so that they are having more environmental awareness.

These finding of the study corroborated with finding of various researchers ${ }^{11-16}$, who reported type of institution have a fact on the level of environmental awareness.

The study reveals that teachers should sustain their attitude about look for the positive development in the students belonging to different parent's educational group rather than the acquisition of bookish information. Teacher can play an important role in educating their students about environment, which is possible only when the teacher themselves have the necessary level of environmental education awareness. Pertinent steps have to be taken to prepare environmentally conscious teachers and citizens. For this purpose, the government should play greater attention towards teachers teaching at school levels. They should introduce and enrich environmental education programmes in both in-service and pre-service teacher education programmes. 
Educational policy maker should reform the curriculum offered in arts and science stream books. The curriculum offered in HP Board schools should also be changed according to CBSE School system. So HP Board students can study deeply with their interest in simple way.

Various activities related to Environmental education like essay writing, mimic etc. can be arranged in schools. Special awareness programmes in the form of seminars symposium, camps and community visits should be arranged among the environmental teachers, students, parents and also masses.

\section{References:-}

1. Patial B.S.; International J. of Engineering Inventions, 5(10),49-52(2016).

2. Ali R. A.; International J. of Education and Research, 3(3), 135-152(2015).

3. Mark R.; Spring,27,1-5(2002)

4. Halder S.; International J. of Environmental Sciences, 2(2),2223-2233(2012).

5. Sandhu P. \& Singh S.; International J. of Scientific Research and Publications,4(1), 1-4,(2014).

6. Shobeiri S. M., Omidvar B. \&Prahallada N.N.; International J. of Environmental Research,1(1),28-34(2007).

7. Rabiu Ali A.; International J. of Science \& Research, 3(3),135-153(2015).

8. Xietal X., Lithong F., \&Xueming D.; Centre for the Integrated Study of the Human Dimensions of Global Change, Carnegie Mellon University, (1998).

9. Singh A., Kumari S. \& Singh J.; Universal J. of Environmental Research and Technology, 4(1),60-64(2016).

10. Sukumar A.; J. of Indian Edu., 31(1),36-43(2005).

11. Patel D.G. \& Patel A.N.; Prog. Edu.LXXIX(12),256-259(1995).

12. Kumar R., Malti\& Kumar N.; Indian J. Env. Edu., 11,27-32(2011).

13. Szagun G. \& Pavlov V., J. Youth Soc., 27(1)93-112(1995).

14. Tripathi M.P. National J. Edu., VI(1)47-51(2000).

15. Nagra V.; International Journal of Advanced Research in Management and social Sciences, 4(4), 116123(2015).

16. Aminrad Z., Sharifah Z. \& Abdul Samad H.; The Social Sciences, 6(1), 15-19(2011). 